\title{
Influence of Stem Diameter, Water Content, and Freezing-Thawing on Bacterial Canker Development in Excised Stems of Dormant Stone Fruit
}

\author{
T. Cao, R. J. Sayler, T. M. DeJong, B. C. Kirkpatrick, R. M. Bostock, and K. A. Shackel
}

First author: Institute of Agricultural Modernization, Academia Sinica, Shijiazhuang, 050021, People's Republic of China; second, fourth, and fifth authors: Department of Plant Pathology, University of California, Davis 95616; and third and sixth authors: Department of Pomology, University of California, Davis 95616. Accepted for publication 4 July 1999.

\begin{abstract}
Cao, T., Sayler, R. J., DeJong, T. M., Kirkpatrick, B. C., Bostock, R. M., and Shackel, K. A. 1999. Influence of stem diameter, water content, and freezing-thawing on bacterial canker development in excised stems of dormant stone fruit. Phytopathology 89:962-966.

In excised dormant stems of peach (Prunus persica), prune (Prunus domestica), and almond (Prunus dulcis), stem diameter, stem hydration, and freezing-thawing influenced the extent of infection caused by Pseudomonas syringae pv. syringae. Bacterial lesion length increased with increasing stem diameter, demonstrating the need to account for the effects of stem diameter when lesion length data are analyzed. Lesion length increased or decreased with stem hydration or dehydration, re-

tissue susceptibility to infection by $P$. syringae pv. syringae, as larger diameter stems had larger lesions and lower water content than did smaller diameter stems. After freezing at $-5^{\circ} \mathrm{C}$ for 12 to $24 \mathrm{~h}$, inoculations made during the thawing process produced significantly larger lesions than did inoculations performed before freezing or after thawing. These results support the hypothesis that the increased susceptibility to bacterial canker that is associated with noninjurious freezing is a result of the increased passive spread of bacteria through water redistribution when inoculation is performed during the thawing process. Plant tissue water relationship characteristics that can influence water movement during freezing and thawing may be an important component of bacterial canker development in stone fruit trees.
\end{abstract} spectively. However, tissue water content was not a good indicator of
Bacterial canker (BC) in California is caused by Pseudomonas syringae pv. syringae and results in serious losses to stone fruit trees due to branch dieback and tree mortality. Research has shown that many factors including soil texture, low soil $\mathrm{pH}$, soil depth, tree nutrition, tree age, nematode parasitism, rootstock selection, cultural practices such as early fall pruning, and environmental factors such as freezing temperatures and rain can influence disease development $(3,4,9)$. Although plant moisture status is generally not regarded as a significant factor for canker development, peach trees growing in light, sandy soils developed significantly more BC when given an autumn irrigation compared with trees not receiving this irrigation (3). Vigouroux and Bussi (15) reported that soil texture could influence tree susceptibility by influencing the water content of stems during the winter. The winter water content of peach stems was about $1.5 \%$ higher in peach trees grown on coarse-textured soils favorable to $\mathrm{BC}$ development compared with stems from trees grown on fine-textured soils. The water content in the stem tissue of some stone fruit trees has been reported to have a marked effect on the potential for bacteria to spread during a frost period and on the extent of the resulting cankers (14). Moreover, a correlation between frost events and infection by $P$. syringae pv. syringae has been reported $(7,11,16)$. One hypothesis proposed to explain the disease development suggests that multiplication of the pathogen prior to freezing utilizes the sugars in the phloem tissue and results in a reduction in sugar levels. As a consequence of the lowered sugar content, the infected phloem and cambium become more sensitive to frost injury and, following frost injury, are more susceptible to the pathogen (8). The ability of $P$. syringae pv. syrin-

Corresponding author: K. A. Shackel; E-mail address: kashackel@ucdavis.edu

Publication no. P-1999-0825-03R

(C) 1999 The American Phytopathological Society gae to nucleate ice is also believed to play an important role in $\mathrm{BC}$ disease of peach $(8,17)$. Vigouroux $(13,14)$ observed that noninjurious freezing caused water-soaking in peach stems and hypothesized that this freezing-induced water-soaking was important in promoting the ingress and spread of $P$. syringae $\mathrm{pv}$. persicae in fruit tree stems. The term water-soaking referred to the translucent appearance of the tissue during thawing, indicating that an increase in the apoplastic water content had occurred as a result of ice accumulation in this zone during freezing. Water movement from the symplast into the apoplast would be expected if ice nucleation occurred in the apoplast and reduced the free energy of water in this compartment relative to the symplast (1). Vigouroux (14) found that both bacteria and marker dyes were passively spread when this apoplastic water was reabsorbed by the cells after thawing and hypothesized that this process, and not the increased apoplastic water content per se, was responsible for the increased levels of $P$. syringae pv. persicae infection under freezing-thawing conditions. Vigouroux (14) also hypothesized that a higher overall stem water content would lead to more apoplastic water movement during freezing-thawing and that soil and other site-specific environmental conditions may lead to differences in BC susceptibility through their effect on stem water content. In this study, we tested the hypothesis that stem water content and noninjurious freezing affects the size of lesions caused by $P$. syringae pv. syringae in peach, prune, and almond stems and evaluated the usefulness of stem water content as an indicator of susceptibility to $P$. syringae pv. syringae infection among these different species and some of their cultivars.

\section{MATERIALS AND METHODS}

Plant materials, bacterial strain, inoculation, stem treatments, and disease evaluation. All experiments were conducted on 1-yearold excised dormant stems, approximately $30 \mathrm{~cm}$ long, of peach 
(Prunus persica (L.) Batsch, cvs. Monaco, Angelus, and Fantasia), prune (Prunus domestica L., cv. French), and almond (Prunus dulcis (Mill.) D.A. Webb) trees growing in the field at the University of California, Davis. The bacterial strain used in all experiments was $P$. syringae pv. syringae strain B3A (2). Prior to inoculation, $P$. syringae pv. syringae was grown in King's medium B (6) for 2 days at $28^{\circ} \mathrm{C}$ with shaking at $180 \mathrm{rpm}$. Bacteria were harvested by centrifugation at $3,000 \times g$ for $7 \mathrm{~min}$ at $4^{\circ} \mathrm{C}$. The bacterial pellet was suspended in sterile distilled water, and the bacterial concentration was adjusted to approximately $10^{8} \mathrm{CFU} / \mathrm{ml}$ as estimated by measuring the optical density at $600 \mathrm{~nm}$. Inoculation was accomplished by puncturing the bark of the stems to the cambium with a needle. Immediately following puncture, drops of bacterial suspension were applied to the wound and one to three drops (about 1 to $3 \mu \mathrm{l}$ ) was absorbed within $5 \mathrm{~s}$, depending on the stem type and cultivar. Three to six inoculations were performed on each stem, and after inoculation, the stems were placed in plastic bags that were then sealed and put in an incubator at $12^{\circ} \mathrm{C}$ for disease development. The extent of canker development was evaluated by cutting the stem tangentially with a razor after 7 to 10 days of incubation and measuring the length and width of the lesion with a caliper. The stem diameter at each inoculation point on each stem was also measured.

Three levels of tissue hydration with and without exposure to freezing-thawing were used to influence the extent of infection by $P$. syringae pv. syringae. The three levels of stem hydration were obtained by allowing the stems to air-dry for 8 to $10 \mathrm{~h}$ at room temperature ( 21 to $23^{\circ} \mathrm{C}$, dehydration treatment), soaking the stems in distilled water for 8 to $10 \mathrm{~h}$ at 5 to $8^{\circ} \mathrm{C}$ (hydration treatment), or harvesting additional stems from the field (fresh treatment) after the 8- to 10-h period used for hydration or dehydration was complete. For the freezing-thawing treatment, stems were exposed to a freezing environment of $-5^{\circ} \mathrm{C}$ for 12 to $24 \mathrm{~h}$ before inoculation. For the nonfrozen treatment, a parallel set of stems was inoculated directly after hydration, dehydration, or collection from the field, respectively.

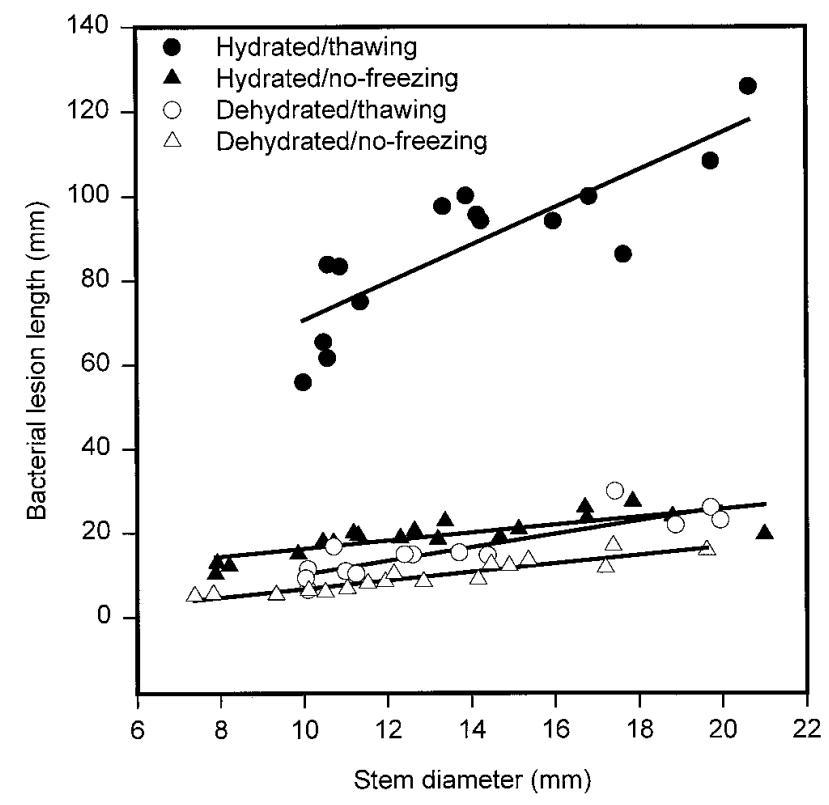

Fig. 1. The relationship between lesion length and stem diameter for selected hydration and temperature treatments in 'Angelus' peach stems. For clarity, each point is the mean lesion length and stem diameter for a single stem, each stem having three to six replicate inoculations. Also shown are the linear regressions between lesion length (L) and stem diameter (D) for the following treatments: hydrated/thawing, $\mathrm{L}=25.99+4.46 \times \mathrm{D}, R^{2}=0.71$; dehydrated/thawing, $\mathrm{L}=$ $-5.81+1.60 \times \mathrm{D}, R^{2}=0.77$; hydrated/no thawing, $\mathrm{L}=6.82+0.94 \times \mathrm{D}, R^{2}=$ 0.64; and dehydrated/no freezing, $\mathrm{L}=-3.37+1.01 \times \mathrm{D}, R^{2}=0.87$.
The water content of stems was assessed by oven-drying at $80^{\circ} \mathrm{C}$ for $72 \mathrm{~h}$ and measuring the change in weight due to water loss. The percent water content was calculated as the change in weight due to water loss divided by the initial fresh weight of the stem. For one experiment, the variation in water content of stems of different diameter in 'Angelus', 'Fantasia', and 'Monaco' peach was measured by harvesting 1-year-old shoot systems, some of which were very long $(2 \mathrm{~m})$, and dividing all shoots into 13 - to $15-\mathrm{cm}$-long sections. The diameter in the middle part of each section was measured in addition to its fresh and dry weight.

Data were analyzed for statistical significance using the general linear model (GLM) procedure (Statistical Analysis System; SAS Institute, Cary, NC). In all cases, least-square (LS) means were used to compare treatments. When appropriate, a power transformation (5) was applied to the data before subjecting it to statistical analysis. Following the recommendation of Fernandez (5), both the power-transformed means and their back-transformed equivalents are presented.

Tissue hydration and freezing-thawing effects on water content and lesion size in 'Angelus' peach. For hydration and dehydration treatments, the stems were harvested on 3 March 1998, with fresh stems harvested the following day. A total of 93 stems with diameters of 6 to $25 \mathrm{~mm}$ were used for inoculations, and an additional 9 to 12 stems representative of this range of diameters were used for water content determination as described above for each treatment. Immediately after the hydration and dehydration treatments, about half of the stems were inoculated with $P$. syringae pv. syringae at room temperature $\left(21\right.$ to $\left.23^{\circ} \mathrm{C}\right)$, and the remainder were placed at $-5^{\circ} \mathrm{C}$ for $12 \mathrm{~h}$ and then inoculated during the thawing process with the same bacterial suspension. The bacterial suspension was kept at $2^{\circ} \mathrm{C}$ during the $12 \mathrm{~h}$ of tissue freezing; later experiments showed no evidence that the concentration or virulence of the bacterial suspension changed over this period of time (data not shown). Visually, the frozen stems required about 5 to 6 min to completely thaw. Small groups of stems were removed from the $-5^{\circ} \mathrm{C}$ freezer and were inoculated between 1 and 2 min after removal. The stem diameter at each inoculation point and the lesion length and width were measured after 7 days of incubation at $12^{\circ} \mathrm{C}$.

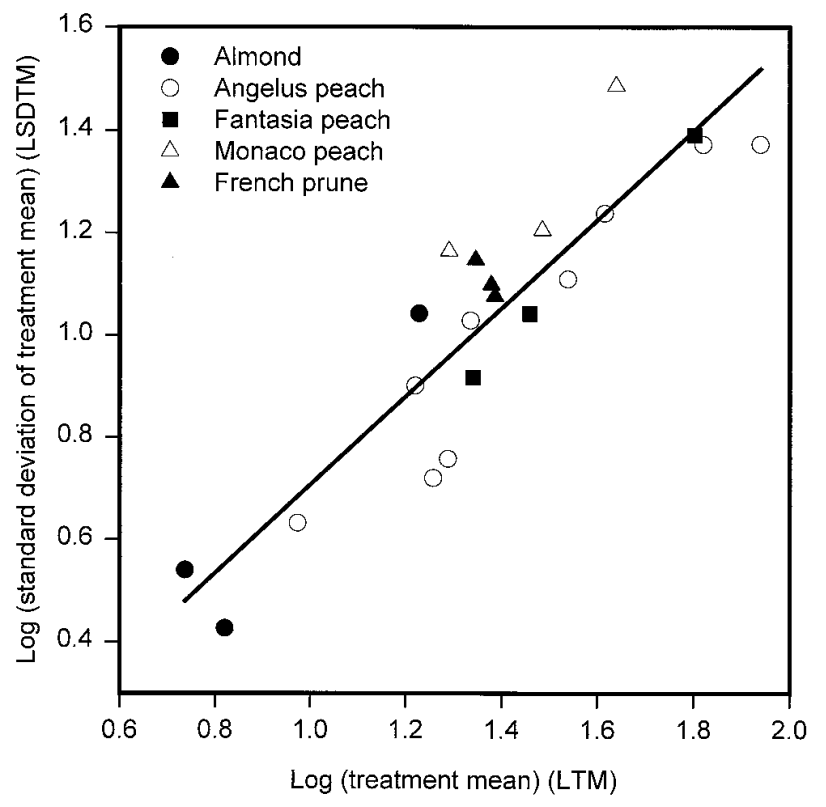

Fig. 2. The relationship between the means and standard deviations of lesion lengths for all treatments, species, and cultivars used in this study. Each point represents the $\log$ of the treatment mean (LTM) and the log of the corresponding treatment standard deviation (LSDTM), with the linear regression also shown $\left(\mathrm{LSDTM}=-0.16+0.86 \times \mathrm{LTM}, R^{2}=0.83\right)$. 
Effect of inoculation at different stages of the freezingthawing treatment in almond. Stems of almond having a narrow range of diameters ( 5 to $7 \mathrm{~mm}$ ) and having been in cold storage $\left(4^{\circ} \mathrm{C}\right)$ were obtained from the Foundation Plant Materials Service at the University of California, Davis. Ten stems each were inoculated before freezing, after thawing, or during the thawing process. Three groups of six additional stems, representative of those used in the inoculation treatments, were used for water content determination as described above. The stem diameter at each inoculation point and the lesion length and width were measured after 7 days of incubation at $12^{\circ} \mathrm{C}$.

Freezing-thawing inoculations and symptom development in peach and prune cultivars. Stems of 'Angelus', 'Monaco', and 'Fantasia' peach, and 'French' prune were harvested on 25 February 1998 using the same protocol for hydration, dehydration, and preparation of fresh samples as described above for 'Angelus' peach. Four to fourteen stems for each of the treatments were used for inoculation in peach, and 18 to 28 stems were used for inoculation in prune. Three additional stems for each treatment were used for fresh and dry weight determination. All stems were exposed to $-5^{\circ} \mathrm{C}$ for $24 \mathrm{~h}$ and were inoculated during thawing. Stem diameter and bacterial lesion length and width at each inoculation point were measured after incubation at $12^{\circ} \mathrm{C}$ for 10 days.

\section{RESULTS}

An analysis of the lesion length data for 'Angelus' peach indicated that, for each treatment, there was a clear increase in lesion length as stem diameter increased (Fig. 1). This analysis also showed that lesion length was greater for hydrated than for dehydrated samples and that lesion length was greater when the inoculation was performed during thawing than when it was performed without freezing-thawing (Fig. 1). In all cases, the lesion length for the fresh pretreatment (data not shown) was close to that of the dehydrated pretreatment, but it was between the corresponding hydration and dehydration pretreatments. The variation in lesion length was not uniform across treatments, however, suggesting that a power transformation may be necessary before subjecting the data to a

TABLE 1. Analysis of variance and covariance for power-transformed lesion length in 'Angelus' peach stems ${ }^{\mathrm{x}}$

\begin{tabular}{lcc}
\hline Source & Degrees of freedom & Mean square \\
\hline Stem diameter & & \\
Error A & 1 & $2.039^{\mathrm{z}}$ \\
Thawing (T) & 362 & 0.002 \\
Hydration (H) & 1 & $2.983^{\mathrm{z}}$ \\
T $\times$ H & 2 & $2.702^{\mathrm{z}}$ \\
Stem within $\mathrm{T} \times \mathrm{H}$ (error B) & 2 & $0.718^{\mathrm{z}}$ \\
\hline
\end{tabular}

${ }^{\mathrm{x}}$ Testing for the effects of stem diameter, inoculation during freezing-thawing treatments, level of stem hydration, and the interaction between thawing and stem hydration.

y Type I sum of square for stem diameter as a covariate.

${ }^{\mathrm{z}} F$ ratio significant at $P<0.001$.

TABLE 2. Effect of tissue hydration and various freezing-thawing inoculation treatments on lesion length in 'Angelus' peach stems

\begin{tabular}{lccc}
\hline Treatment & $\begin{array}{c}\text { No. of lesions } \\
\text { measured }\end{array}$ & LS mean & Lesion \\
length & $(\mathrm{mm})$ \\
\hline Hydrated/thawing & 62 & $1.86 \mathrm{a}$ & $82.66 \pm 3.61$ \\
Fresh/thawing & 62 & $1.62 \mathrm{~b}$ & $31.44 \pm 1.56$ \\
Hydrated/no freezing & 101 & $1.51 \mathrm{c}$ & $19.11 \pm 0.80$ \\
Fresh/no freezing & 75 & $1.49 \mathrm{c}$ & $17.18 \pm 0.82$ \\
Dehydrated/thawing & 72 & $1.45 \mathrm{~d}$ & $14.40 \pm 0.73$ \\
Dehydrated/no freezing & 89 & $1.37 \mathrm{e}$ & $9.44 \pm 0.50$ \\
\hline
\end{tabular}

${ }^{y}$ LS mean: least-square mean (power-transformed). Means followed by the same letter are not different at $P<0.05$ according to pairwise $t$ tests.

${ }^{\mathrm{z}}$ Back-transformed LS mean \pm estimate of 1 standard error. formal statistical analysis. By pooling the data obtained from all cultivars and treatments, it was clear that the variability in lesion length increased as mean lesion length increased (Fig. 2), and following Fernandez (5), the slope of the regression for the log of the treatment standard deviation with the log of the treatment mean was used to determine the appropriate transformation power. For all cultivars, this pooled estimate represented an exponent of 0.14 , which was used to transform all lesion length data.

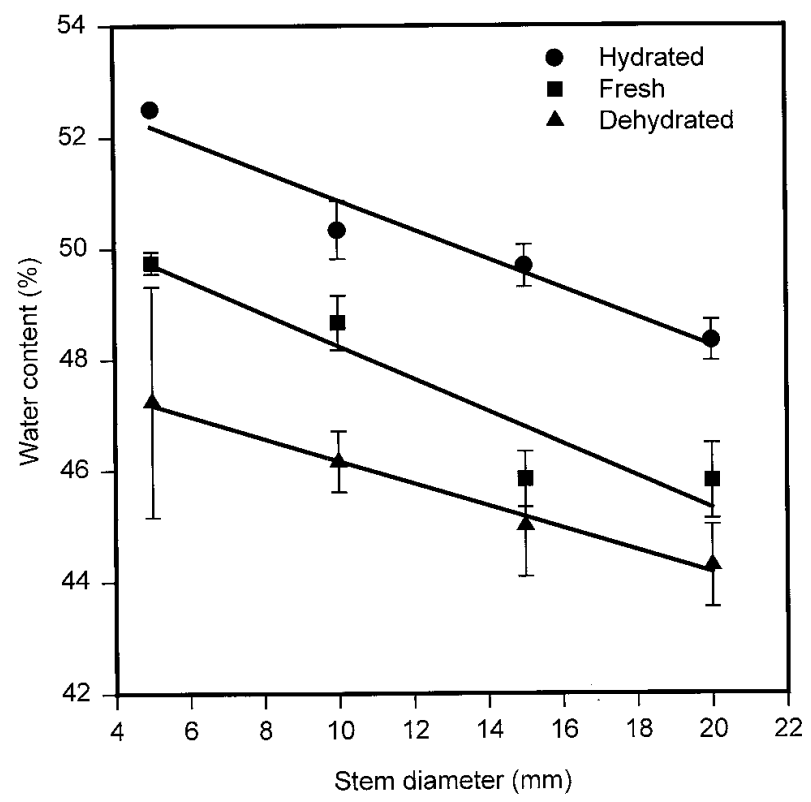

Fig. 3. Water content in 'Angelus' peach stems of different diameters harvested directly from the field (fresh) or exposed to air (dehydrated) or water (hydrated) for 8 to $10 \mathrm{~h}$. Points shown are means \pm 1 standard error $(n=3)$ for each stem diameter class (error bars smaller than the symbol are hidden), with the linear regression between water content (WC) and stem diameter (D) drawn through all individual points. Hydrated, $\mathrm{WC}=53.51-0.26 \times \mathrm{D}, R^{2}=0.85$; fresh, $\mathrm{WC}=51.18-0.29 \times \mathrm{D}, R^{2}=0.76$; and dehydrated, $\mathrm{WC}=48.18-$ $0.20 \times \mathrm{D}, R^{2}=0.30$.

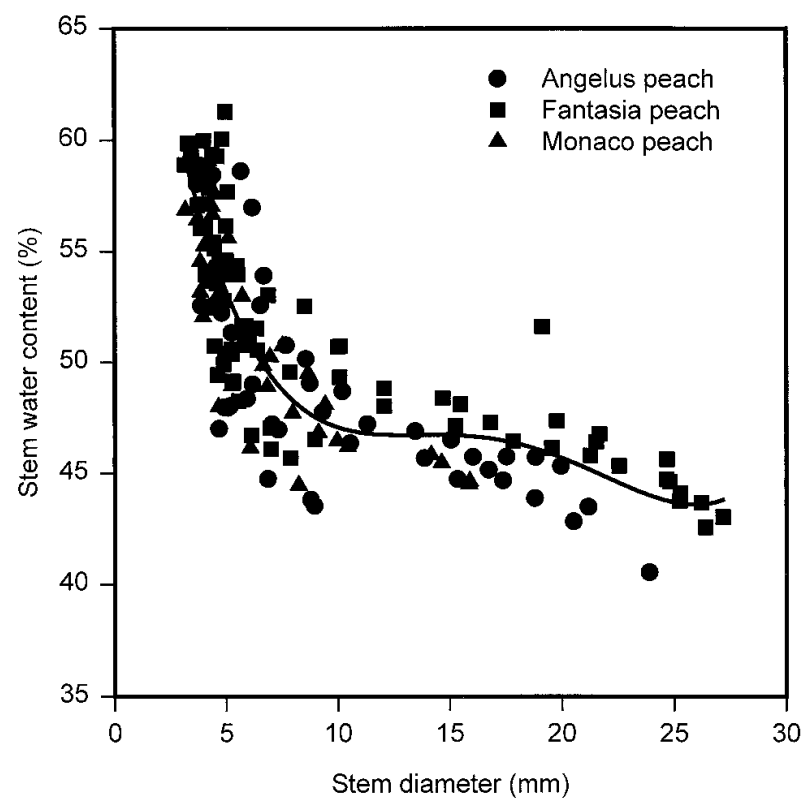

Fig. 4. Variation in the water content (WC) of freshly harvested 1-year-old dormant stems of different diameters (D) for three varieties of peach. Each point represents an individual stem, with a polynomial regression fitted to all points $\left(\mathrm{WC}=77.69-7.88 \times \mathrm{D}+7.32 \mathrm{E}-1 \times \mathrm{D}^{2}-2.91 \mathrm{E}-2 \times \mathrm{D}^{3}+4.10 \mathrm{E}-4 \times\right.$ $\left.\mathrm{D}^{4}, R^{2}=0.71\right)$ 
For 'Angelus' peach, the formal statistical analysis of the transformed lesion length data showed that stem diameter was a highly significant covariate (Table 1). The appropriate error for this term was based on individual measurements, because stem diameter was measured separately at each inoculation point. None of the interaction terms between stem diameter and the other sources of variation were significant (data not shown), indicating that the effect of stem diameter was consistent for all treatment combinations (there was no heterogeneity of slope), with lesion length increasing as stem diameter increased (Fig. 1). Equivalent results were also obtained when using lesion area (length $\times$ width). The main effects of the hydration and freezing-thawing treatments on lesion length were also highly significant, as was their interaction (Table 1). Since individual inoculations on a single stem represented subsamples, the appropriate error for testing these effects was the variability of stems within each treatment combination. Treatment effects were compared by using LS means of lesion length, which were adjusted for the effects of stem diameter. Also, to interpret the significant hydration $\times$ freezing-thawing interaction (Table 1), LS means for the individual treatment combinations were compared. For these means, the combination of hydration with freezing-thawing produced the largest lesions, whereas dehydration of nonfrozen samples produced the smallest (Table 2). For any given hydration treatment, lesions were larger for frozen-thawed stems than for nonfrozen stems, and for any given temperature treatment, lesions were largest for hydrated, intermediate for fresh, and least for dehydrated stems (Table 2). Separation of these LS means was based on pairwise $t$ tests, using the stem within treatment combination error term (Table 1), but identical separation patterns were also obtained using normal means and Duncan's test (data not shown). Also, to aid in interpreting the magnitude of these effects, the reverse-transformed LS means and an estimate of their standard errors are also presented (Table 2). These standard errors were obtained by reversetransforming each LS mean plus or minus its standard error and dividing the difference between these two values by 2 . The interaction between hydration and freezing-thawing treatments was significant (Table 1), because the magnitude of the freezing-thawing effect was different for different levels of hydration, with a pro-

TABLE 3. Effect of different freezing-thawing inoculation treatments on lesion length development in excised almond stems

\begin{tabular}{lccrc}
\hline $\begin{array}{l}\text { Time of } \\
\text { inoculation }\end{array}$ & $\begin{array}{c}\text { No. of } \\
\text { lesions } \\
\text { measured }\end{array}$ & $\begin{array}{c}\text { LS mean } \\
\text { of lesion } \\
\text { length }^{\mathrm{x}}\end{array}$ & $\begin{array}{c}\text { Lesion } \\
\text { length } \\
(\mathrm{mm})\end{array}$ & $\begin{array}{c}\text { Stem water } \\
\text { content }^{\mathrm{z}} \\
(\%)\end{array}$ \\
\hline During thawing & 40 & $1.45 \mathrm{a}$ & $14.15 \pm 1.43$ & $45.51 \pm 0.71$ \\
After thawing & 40 & $1.29 \mathrm{~b}$ & $6.21 \pm 0.70$ & $45.32 \pm 0.21$ \\
Before freezing & 40 & $1.25 \mathrm{~b}$ & $4.82 \pm 0.57$ & $45.28 \pm 0.47$ \\
\hline
\end{tabular}

${ }^{x}$ LS mean: least-square mean (power-transformed). Means followed by the same letter are not different at $P<0.05$ according to pairwise $t$ tests.

y Back-transformed LS mean \pm estimate of 1 standard error.

${ }^{\mathrm{z}}$ Mean \pm 1 standard error $(n=6)$. Stem water content was determined as percent change in weight after oven-drying at $80^{\circ} \mathrm{C}$ for $72 \mathrm{~h}$.

TABLE 4. Analysis of variance and covariance for power-transformed lesion length in 'Angelus', 'Fantasia', and 'Monaco' peach, and 'French' prune inoculated during thawing ${ }^{\mathrm{x}}$

\begin{tabular}{lcc}
\hline Source & Degrees of freedom & Mean square \\
\hline Stem diameter $^{\mathrm{y}}$ & 1 & $4.560^{\mathrm{z}}$ \\
Error A & 507 & 0.006 \\
Cultivar (C) & 3 & $0.200^{\mathrm{z}}$ \\
Hydration (H) & 2 & $1.324^{\mathrm{z}}$ \\
$\mathrm{C} \times \mathrm{H}$ & 6 & $0.191^{\mathrm{z}}$ \\
Stem within C $\times \mathrm{H}$ (error B) & 128 & 0.024 \\
\hline
\end{tabular}

$\mathrm{x}$ Testing for the effects of stem diameter, cultivar, level of stem hydration, and the interaction between cultivar and stem hydration treatments.

y Type I sum of square for stem diameter as a covariate.

${ }^{\mathrm{z}} F$ ratio significant at $P<0.001$. gressively greater effect of freezing-thawing as the level of hydration increased (Table 2).

Stem water content was increased by hydration and decreased by dehydration, but stem water content was also related to stem diameter, with larger diameter stems having lower water contents than did smaller diameter stems. In 'Angelus' peach, the decrease in water content between hydrated and dehydrated treatments was similar in magnitude to the decrease in water content from the smallest to the largest diameter stems (Fig. 3). Freshly harvested stems of all peach cultivars studied also showed a nonlinear but overall negative relationship of stem water content to stem diameter, with water contents ranging between 60 and $45 \%$ for stems of 4 to $25 \mathrm{~mm}$ in diameter, respectively (Fig. 4).

In almond stems having a narrow range of diameters (5 to $7 \mathrm{~mm}$ ), there was no significant diameter effect on lesion length (data not shown), but there was a highly significant effect of inoculation timing, with the largest lesion length produced when the stems were inoculated during thawing compared with inoculation before freezing or after thawing (Table 3).

For all cultivars, the formal statistical analysis of transformed lesion length data indicated that stem diameter, tissue hydration, cultivar, and hydration $\times$ cultivar effects were all highly significant (Table 4). As for the data presented in Table 1, the stem diameter effect was consistent (there was no heterogeneity of slope) across all cultivars and treatments, with lesion length increasing as stem diameter increased (data not shown). Also, similar to the data presented in Table 2, the significant interaction between hydration and cultivar was due to a larger effect of hydration on lesion length in some cultivars than in others (data not shown). Across all cultivars, lesion length significantly increased with increasing hydration (Table 5). For these cultivars, 'Fantasia' peach generally exhibited the largest lesion length and 'Monaco' peach the least (Table 6). Even though tissue hydration had a clear impact on lesion length in all cases studied (Tables 2 and 5), there was no relationship between the water content of tissue and the extent of lesion development between species or cultivars, with 'Fantasia' and 'Monaco' peach exhibiting the most contrasting lesion lengths but similar water contents (Table 6). In all cases, equivalent results were ob-

TABLE 5. Effect of hydration treatments across all Prunus species and cultivars (Angelus, Fantasia, and Monaco peach, and French prune) on lesion length for stems inoculated during thawing

\begin{tabular}{lcccc}
\hline Treatment & $\begin{array}{c}\text { No. of lesions } \\
\text { measured }\end{array}$ & LS mean $^{\mathrm{x}}$ & $\begin{array}{c}\text { Lesion } \\
\text { length }^{\mathrm{y}}(\mathrm{mm})\end{array}$ & $\begin{array}{c}\text { Stem water } \\
\text { content }^{\mathrm{z}}(\%)\end{array}$ \\
\hline Hydrated & 242 & $1.66 \mathrm{a}$ & $37.88 \pm 2.53$ & $52.71 \pm 0.94$ \\
Fresh & 231 & $1.56 \mathrm{~b}$ & $24.10 \pm 1.69$ & $49.54 \pm 1.04$ \\
Dehydrated & 186 & $1.47 \mathrm{c}$ & $15.52 \pm 1.24$ & $46.85 \pm 0.78$ \\
\hline
\end{tabular}

${ }^{x}$ LS mean: least-square mean (power-transformed). Means followed by the same letter are not different at $P<0.05$ according to pairwise $t$ tests.

y Back-transformed LS mean \pm estimate of 1 standard error.

${ }^{\mathrm{z}}$ Mean \pm 1 standard error $(n=12)$. Stem water content was determined as percent change in weight after oven-drying at $80^{\circ} \mathrm{C}$ for $72 \mathrm{~h}$.

TABLE 6. Effect of species and cultivar across all levels of hydration (hydrated, fresh, and dehydrated) on lesion length and water content of stems inoculated during thawing

\begin{tabular}{lcccc}
\hline Cultivar & $\begin{array}{c}\text { No. of lesions } \\
\text { measured }\end{array}$ & $\begin{array}{c}\text { LS } \\
\text { mean }^{\mathrm{x}}\end{array}$ & $\begin{array}{c}\text { Lesion } \\
\text { length }^{\mathrm{y}}(\mathrm{mm})\end{array}$ & $\begin{array}{c}\text { Stem water } \\
\text { content }^{\mathrm{z}}(\%)\end{array}$ \\
\hline Fantasia peach & 144 & $1.62 \mathrm{a}$ & $31.14 \pm 1.94$ & $51.01 \pm 0.89$ \\
Angelus peach & 82 & $1.56 \mathrm{ab}$ & $24.41 \pm 4.20$ & $50.40 \pm 1.47$ \\
Monaco peach & 100 & $1.51 \mathrm{~b}$ & $19.18 \pm 2.19$ & $51.21 \pm 1.41$ \\
French prune & 333 & $1.56 \mathrm{~b}$ & $24.19 \pm 2.07$ & $46.19 \pm 0.74$ \\
\hline
\end{tabular}

x LS mean: least-square mean (power-transformed). Means followed by the same letter are not different at $P<0.05$ according to pairwise $t$ tests.

y Back-transformed LS mean \pm estimate of 1 standard error.

${ }^{\mathrm{z}}$ Mean \pm 1 standard error $(n=9)$. Stem water content was determined as percent change in weight after oven-drying at $80^{\circ} \mathrm{C}$ for $72 \mathrm{~h}$. 
tained using lesion length alone or lesion area (length $\times$ width) (data not shown).

\section{DISCUSSION}

The availability of water in the intercellular spaces of plant tissue is thought to play an important role in BC development (18). Field experiments have shown that trees irrigated late in the fall were more susceptible to $\mathrm{BC}$ caused by $P$. syringae pv. syringae than were trees not experiencing a late-fall irrigation (4). Together with freezing-thawing, slight differences in stem water content have been associated with large differences (often as much as $40 \%$ ) in the ability of dye to spread in stem cortical tissues and in the length of cankers caused by $P$. syringae pv. persicae (14). Our work also indicates that artificially increasing or decreasing the water content of dormant stems results in increases or decreases in bacterial lesion length, respectively. Across a number of Prunus species, a 6\% increase in water content (from 47 to $53 \%$ ) resulted in a more than doubling of bacterial lesion length (Table 5). Similar or much larger relative increases in lesion length, however, were also associated with an increase in stem diameter (Fig. 1), which was associated with a decrease in water content of about $4 \%$ (Fig. 3) for the range of diameters shown in Figure 1. Hence, the wide range of water contents in 1-year-old stems (Fig. 4) probably precludes the use of water content as a simple indicator of tissue susceptibility to disease development. Whole-stem water content may be related to the relative proportions of wood and bark tissues rather than a measure of the water potentially available for movement into the intercellular spaces during freezing $(1,10)$.

The influence of tissue freezing on the development of $P$. syringae pv. syringae has been studied in some detail, but the interaction between freezing and the level of tissue hydration on development of $P$. syringae pv. syringae deserves further study. Cambial necrosis was more extensive when apricot $(7,8)$ and peach $(16)$ branches were frozen following inoculation with $P$. syringae pv. syringae compared with nonfrozen branches. Cherry leaves were infected only when ice formed in the intercellular spaces; however, infection was not related to low temperature, but instead, to the formation of ice in the presence of $P$. syringae pv. syringae (12). At low temperatures $\left(-1\right.$ to $\left.-10^{\circ} \mathrm{C}\right)$, once ice nucleation occurs in the apoplast, migration of water from the symplast to the apoplast is expected $(1,10)$. When temperatures rise and this ice thaws, continuous films of water should form in the apoplast until the cells reabsorb this intercellular water (13). Bark cankers with a characteristic water-soaked appearance and "sour-sap" odor developed only on stems that were frozen at $-10^{\circ} \mathrm{C}$ and then inoculated with $P$. syringae pv. syringae and incubated at $15^{\circ} \mathrm{C}(16)$. These cankers on peach stems resulted from an interaction between infection by $P$. syringae pv. syringae and freezing injury, as neither freezing nor inoculation of $P$. syringae pv. syringae alone produced cankers (16). If it is the movement of apoplastic water that promotes disease development, as suggested by Vigouroux (14), then it may be reasonable to consider factors in addition to tissue water content such as cell osmotic potential, tissue total water potential, or tissue moisture-release characteristics, which may influence the extent of this movement (1). For instance, under typical winter dormancy conditions, it is likely that stems of different diameters from the same plant will have the same total water potential, so that using water potential as a measure of tissue hydration may avoid much of the apparent variability in tissue hydration that was observed in this study (Fig. 4). It is also possible that water potential may be more closely related to freezing-thawing-induced water movement and disease development than to water content. The relationship between stem diameter and lesion length even for fully hydrated stems (Fig. 1), however, may indicate that different tissue types or other physiological factors are also important. In any case, we recommend that statistical analyses of such lesion length data should probably be based on a power transformation (Fig. 2), with stem diameter as covariate (Table 1).

Our results are consistent with the hypothesis of Vigouroux (14), that BC development involves the interactive effects of bacterial presence, tissue freezing, and tissue hydration levels. We further suggest that tissue water content may not be an adequate measure of the degree to which symplast/apoplast water movement will occur during freezing and thawing and that additional research into this aspect of disease development is warranted.

\section{ACKNOWLEDGMENTS}

This work was funded, in part, by The California Prune Board. T. Cao thanks the K. C. Wong Education Foundation, Hong Kong, for their support. We also thank D. V. Shaw, Department of Pomology, University of California, Davis, for his statistical advice; and H. English, Department of Plant Pathology, University of California, Davis, for careful review of the manuscript.

\section{LITERATURE CITED}

1. Burke, M. J., Gusta, L. V., Quamme, H. A., Weiser, C. J., and Li, P. H. 1976. Freezing and injury in plants. Annu. Rev. Plant Physiol. 27:507-528.

2. DeVay, J. E., Lukezic, F. L., Sinden, S. L., English, H., and Coplin, D. L. 1968. A biocide produced by pathogenic isolates of Pseudomonas syringae and its possible role in the bacterial canker disease of peach trees. Phytopathology 58:95-101.

3. English, H., Davis, J. R., DeVay, J. E., and Lownsbery, B. F. 1980. Bacterial canker, an important decline disease of apricots and other stone fruits in California. Acta Hortic. 85:235-242.

4. English, H., DeVay, J. E., Lilleland, O., and Davis, J. R. 1961. Effect of certain soil treatments on the development of bacterial canker in peach trees. (Abstr.) Phytopathology 51:65.

5. Fernandez, G. C. J. 1992. Residual analysis and data transformations: Important tools in statistical analysis. HortScience 27:297-300.

6. King, E. O., Ward, M. K., and Raney, D. E. 1954. Two simple media for the demonstration of pyocyanin and fluorescin. J. Lab. Clin. Med. 44: 301-307.

7. Klement, Z., Rozsnyay, D. S., and Arsenijevic, M. 1974. Apoplexy of apricots. III. Relationship of winter frost and the bacterial canker dieback of apricots. Acta Phytopathol. Entomol. Hung. 9:35-45.

8. Klement, Z., Rozsnyay, D. S., Báló, E., Pánczél, M., and Prileszky, G. 1984. The effect of cold on development of bacterial canker in apricot trees infected with Pseudomonas syringae pv. syringae. Physiol. Plant Pathol. 24:237-246.

9. Lownsbery, B. F., English, H., Noel, G. R., and Schick, F. J. 1977. Influence of Nemaguard and Lovell rootstocks and Macroposthonia xenoplax on bacterial canker of peach. J. Nematol. 9:221-224.

10. Olien, C. R. 1967. Freezing stresses and survival. Annu. Rev. Plant Physiol. 18:387-408.

11. Sobiczewski, P., and Jones, A. L. 1992. Effect of exposure to freezing temperatures on necrosis in sweet cherry shoots inoculated with Pseudomonas syringae pv. syringae or $P$. s. morsprunorum. Plant Dis. 76: 447-451.

12. Süle, S., and Seemüller, E. 1987. The role of ice formation in the infection of sour cherry leaves by Pseudomonas syringae pv. syringae. Phytopathology 77:173-177.

13. Vigouroux, A. 1989. Ingress and spread of Pseudomonas in stems of peach and apricot promoted by frost-related water-soaking of tissues. Plant Dis. 73:854-855.

14. Vigouroux, A. 1997. Role of frost and stem water content on the development of bacterial canker in acclimated stone fruit trees. Pages 97-102 in: Pseudomonas syringae Pathovars and Related Pathogens. K. Rudolph, T. J. Burr, J. W. Mansfield, D. Stead, A. Vivian, and J. von Kietzell, eds. Kluwer Academic Publishers, Dordrecht, the Netherlands.

15. Vigouroux, A., and Bussi, C. 1994. Une action possible des sols sur la prédisposition des pêchers au dépérissement bactérien par modification de la teneur en eau hivernale des tiges. Agronomie 14:319-326.

16. Weaver, D. J. 1978. Interaction of Pseudomonas syringae and freezing in bacterial canker on excised peach twigs. Phytopathology 68:1460-1463.

17. Weaver, D. J., Gonzalez, C. F., and English, H. 1981. Ice nucleation by Pseudomonas syringae associated with canker production in peach. (Abstr.) Phytopathology 71:109-110.

18. Young, J. M. 1974. Effect of water on bacterial multiplication in plant tissue. N.Z. J. Agric. Res. 17:115-119. 